\title{
HUBUNGAN ANTARA TIPE KEPRIBADIAN BIG FIVE DENGAN ADIKSI INTERNET PADA MAHASISWA DI SURABAYA
}

Tiek Budysan ${ }^{1}$

Fransisca Febriana Sidjaja ${ }^{2}$

Fakultas Psikologi Universitas Katolik Widya Mandala Surabaya

\begin{abstract}
ABSTRAKSI
Adiksi internet merupakan fenomena yang umum ditemui, terutama pada kaum muda. Salah satu faktor yang diyakini sebagai penyebab adiksi internet adalah kepribadian. Penelitian ini bertujuan untuk melihat apakah terdapat hubungan antara tipe kepribadian menurut Big Five Personality (extraversion, agreeableness, conscientiousness, neuroticism, dan openness) dengan adiksi internet pada mahasiswa di Surabaya. Dalam penelitian ini, sebanyak 151 mahasiswa yang mengalami adiksi internet direkruit dengan metode purposive sampling. Hasil uji hubungan menggunakan teknik korelasi non-parametrik Kendall's Tau $b$ mendapatkan hasil bahwa neuroticism adalah satu-satunya dimensi dalam Big Five yang memiliki hubungan dengan adiksi internet $(r=0,121, p=0,034 ; p<0,05)$. Dengan demikian, dapat disimpulkan bahwa tidak ada dimensi kepribadian Big Five yang berkorelasi dengan adiksi internet kecuali neuroticism.
\end{abstract}

Kata Kunci: Adiksi internet, Big Five, mahasiswa, neuroticism, Surabaya akan lebih baik

\section{ABSTRACT}

Internet addiction is a phenomenon generally present among youngsters. One of the factors suggested to be the cause of internet addiction is personality. The present study aims to investigate the relationship between types of personality based on Big Five Theory (extraversion, agreeableness, conscientiousness, neuroticism, and openness) and internet addiction among university students in Surabaya. Within this study, 151 university students with internet addiction in Surabaya were recruited using purposive sampling method. Using the Kendall's Tau b non-parametric correlation technique, the current study found that neuroticism is the only Big Five personality type that shows a significant relationship with internet addiction $(r=0,121, p=0,034 ; p<0,05)$. Thus, it can be concluded that there is no Big Five personality dimension that correlates with internet addiction except neuroticism.

Keywords: Internet addiction, Big Five, university students, Surabaya will be better 


\section{PENDAHULUAN}

Internet adalah hasil perkembangan teknologi yang dibutuhkan oleh hampir semua orang dewasa ini, termasuk masyarakat Indonesia. Di tahun 2013, terdapat 63 juta pengguna internet (Kementrian Komunikasi dan Informatika Republik Indonesia, 2013). Jumlah tersebut meningkat menjadi 104,96 juta pengguna pada tahun 2017 ("Number of internet users in Indonesia from 2015 to 2022", 2017). Meskipun memiliki banyak manfaat, internet juga dapat menimbulkan adiksi. Adiksi internet mulai menarik perhatian para peneliti setelah Kimberly Young mengangkatnya dalam pertemuan American Psychological Association pada tahun 1996 (Young, K. S. \& Abreu, C. N. D, 2011).

Secara umum adiksi internet adalah gangguan adiksi perilaku yang dicirikan dengan penggunaan internet secara berlebihan hingga mengganggu kehidupan sehari-hari. Seorang individu dikatakan mengalami adiksi internet apabila individu tersebut mengalami empat kondisi berikut (Young \& Abreu, 2011: 22): menunda kebutuhan dasar seperti makan dan tidur demi internet (excessive use), merasa marah dan gelisah saat tidak dapat mengakses internet (withdrawal), waktu penggunaan internet yang terus meningkat (tolerance), dan munculnya tanda-tanda seperti merasa lelah, berbohong ataupun menyendiri.

Dari segi tingkat prevalensi adiksi internet, penelitian Cheng dan Li (2014) menemukan bahwa rata-rata tingkat prevalensi adiksi internet di 31 negara adalah sebesar 6\%. Meskipun jumlah tersebut tidak terlihat besar, namun pemerintah beberapa negara, seperti Tiongkok, Korea Selatan, Taiwan, Amerika, Belanda dan Inggris menanggapi dengan serius permasalahan ini dengan membangun pusat rehabilitasi bagi pecandu internet (Wallace, 2014). Selain pemerintah negara, adiksi internet juga menjadi topik penelitian di berbagai negara.

Dari berbagai penelitian tersebut, Young dan Abreu (2011) mengungkapkan bahwa mahasiswa adalah kelompok yang paling rentan mengalami adiksi dengan prevalensi $13 \%$ hingga 18,4\%. Sedangkan prevalensi pada kalangan remaja sebesar 4,6\% hingga 4,7\%, serta $6 \%$ hingga $15 \%$ pada masyarakat umum. Menurut peneliti, tingginya resiko mahasiswa mengalami adiksi internet dipengaruhi oleh faktor internal dan eksternal. Untuk faktor internal, mahasiswa berada dalam masa emerging adulthood yang menuntut mereka untuk mematangkan jati diri mereka (Arnett, 2000). Emerging Adulthood adalah tahapan yang berada diantara remaja akhir dan dewasa awal dengan batas usia 18 hingga 25 tahun. Pada tahap ini, seseorang berada di masa terkahir untuk mematangkan jati diri dikarenakan mereka memiliki kebebasan sebagai orang dewasa namun mereka belum memiliki 
tanggung jawab sebagai orang tua. Tugas mematangkan jati diri rawan membuat mahasiswa mengalami stres dan menggunakan internet sebagai tempat pelarian (Hall \& Parsons, 2001). Sedangkan dari sisi eksternal, mahasiswa dapat dengan mudah mengakses internet secara gratis tanpa ada pengawasan dari orang tua ataupun pihak lain (Young, n.d., para. 2).

Young dan Abreu (2011: 6-13) mengemukakan empat pendekatan mengenai penyebab adiksi internet: (1) Cognitive-Behavioral Model: individu dengan kecemasan tinggi cenderung menggunakan internet sebagai sarana pelarian dan membuat mereka terus menggunakan internet dengan waktu yang terus bertambah, (2) Neuropsychological Model: kenikmatan yang didapat saat menggunakan internet memicu dorongan primitif dalam diri seseorang untuk terus mendapatkan kenikmatan lebih dengan menggunakan internet dengan waktu lebih lama, (3) Compensation Theory: kegagalan individu untuk membangun relasi ataupun mendapatkan prestasi yang berarti di dunia nyata mendorong individu menggunakan internet untuk mendapatkan dukungan sosial (melalui media sosial) ataupun prestasi (didalam game online), (4) Situational Factors: selain kecemasan, individu dengan tingkat stres yang tinggi juga rentan menggunakan internet sebagai cara coping dan mengalami adiksi.

Selain empat pendekatan tersebut, Young dan Abreu (2011) menyarankan agar penelitian selanjutnya meneliti keterkaitan faktor-faktor seperti kepribadian, dinamika keluarga, dan kemampuan interpersonal individu dengan adiksi internet. Sayangnya, sejauh yang peneliti ketahui, penelitian di Indonesia yang meneliti hubungan antara adiksi internet dengan kepribadian masih sedikit. Padahal dengan mengetahui hubungan antara adiksi internet dengan kepribadian, praktisi kesehatan mental dapat mengembangkan intervensi yang efektif (Young \& Abreu, 2011).

Dalam penelitian ini, peneliti menggunakan teori kepribadian dari Goldberg (1990) yang dikenal dengan nama Big Five. Kepribadian Big Five terdiri dari lima dimensi, yaitu: extraversion (dimensi yang berkaitan dengan asertivitas dan antusiasme bersosialisasi), agreeableness (dimensi yang berkaitan dengan keramahan dan sikap kooperatif), neuroticism (dimensi yang berkaitan dengan kecemasan dan pengendalian emosi), conscientiousness (dimensi yang berkaitan dengan ketekunan dan kedisiplinan), dan openness (dimensi yang berkaitan dengan keterbukaan pada pengalaman dan kreatifitas).

Menurut penelitian sejenis yang pernah dilakukan oleh Zhou, Li, Li, Wang dan Zhao (2016) pada remaja, dua dimensi dari Big Five (conscientiousness dan agreeableness) dapat mengurangi kemungkinan seseorang mengalami adiksi internet. Hal ini 
dikarenakan dimensi conscientiousness membantu seseorang memiliki pengendalian diri yang baik sehingga mereka dapat mengontrol frekuensi penggunaan internet. Sedangkan agreeableness memudahkan seseorang membangun relasi sosial di dunia nyata sehingga mereka tidak terlalu bergantung pada media sosial untuk mendapat dukungan sosial.

Sedangkan dimensi neuroticism meningkatkan resiko munculnya adiksi internet pada seseorang, hal ini dikarenakan dimensi tersebut membuat seseorang mudah mengalami stres dan kesulitan dalam menjalin relasi dengan orang lain. Hal-hal tersebut dapat mendorong seseorang menjadikan internet sebagai tempat pelarian, dan pada akhirnya orang tersebut akan menjadi semakin bergantung pada internet.

Terakhir, dimensi extraversion dan openness merupakan dimensi yang memiliki pengaruh yang tidak menentu. Hal ini dikarenakan kedua dimensi tersebut memiliki traittrait yang dapat mengurangi tetapi juga dapat meningkatkan resiko adiksi internet. Extraversion membuat seseorang mudah bersosialisasi, tetapi juga membuat mereka lebih impulsif. Sedangkan openness mendorong seseorang mencoba beragam aktivitas, baik aktivitas positif maupun negatif.

Melalui penelitian ini, peneliti bermaksud untuk melihat apakah ada hubungan antara masing-masing dimensi Big Five dengan adiksi internet pada mahasiswa Surabaya.

\section{METODE PENELITIAN}

\section{PARTISIPAN PENELITIAN}

Teknik pengambilan sampel pada penelitian ini menggunakan purposive sampling, dimana peneliti merekruit orang-orang yang memiliki kesamaan ciri-ciri yang kuat dengan ciriciri populasi (Wasito dkk, 1990: 62). Sedangkan variabel-variabelnya adalah kelima dimensi kepribadian Big Five sebagai indepedent variable dan adiksi internet sebagai dependent variable.

Populasi yang hendak diteliti adalah mahasiswa di Surabaya yang memiliki akses internet dan berusia 18 hingga 25 tahun. Peneliti mengambil populasi pada mahasiswa Surabaya dikarenakan banyak mahasiswa di Surabaya yang tinggal sendirian di tempat kos, sehingga tidak adanya batasan dari orang tua ataupun pihak lain mengenai berapa lama dan apa yang mereka akses di internet. Selain itu, mahasiswa umumnya mampu berpergian sendiri ke tempat-tempat publik yang menyediakan akses wifi gratis. Young (n.d.) menyatakan bahwa salah satu penyebab adiksi internet di kalangan mahasiswa adalah kurangnya pengawasan selama mereka menggunakan internet.

Mahasiswa yang menjadi subjek penelitian adalah mereka yang memenuhi ketiga 
kriteria populasi tersebut dan mendapat skor diatas 33,738 pada Skala Adiksi Internet (SAI). Batasan skor tersebut mengacu pada standar skoring dari Nugraini (2015).

Dari hasil penyebaran data, skala yang telah terisi berjumlah 190 buah. Dari jumlah tersebut, peneliti mengeliminasi data dari 39 subjek yang tidak memenuhi kriteria sehingga data yang dapat dipakai adalah dari 151 subjek. Dari 151 subjek penelitian, 62 orang responden berjenis kelamin laki-laki dan 89 orang perempuan. Sedangkan dalam segi usia, responden terbanyak berusia 21 tahun (45 orang), kemudian responden dengan usia 19 tahun sebanyak 28 orang, responden berusia 20 tahun sebanyak 26 orang, responden berusia 22 tahun sebanyak 23 orang, responden berusia 18 tahun sebanyak 20 orang, serta usia responden yang paling sedikit adalah 23 (5 orang) dan 24 tahun (4 orang).

\section{ALAT UKUR}

Alat ukur yang digunakan dalam penelitian ini adalah Skala Adiksi Internet oleh Nugraini (2015) dan Big Five Inventory versi Indonesia oleh Ramdhani (2012). Skala Adiksi Internet merupakan skala Likert yang terdiri dari 20 aitem favorable, dengan lima alternatif jawaban untuk setiap aitem, yaitu tidak pernah, kadang, sering, sangat sering, dan selalu. Aitem-aitem tersebut dibuat berdasarkan enam aspek, yaitu (1) internet menjadi prioritas utama dalam hidup, (2) penggunaan internet secara berlebihan, (3) pengabaian pekerjaan dan tanggung jawab karena internet, (4) sering munculnya pikiran mengenai internet saat offline, (5) kesulitan untuk mengontrol waktu untuk menggunakan internet, dan (6) pengabaian terhadap lingkungan sosial karena internet (Nugraini, 2015: 21-22). Masing-masing aitem dalam Skala Adiksi Internet tersebut memiliki daya diskriminasi aitem dari 0,311 hingga 0,628, dan reliabilitas sebesar 0,9 (Nugraini, 2015).

Untuk Skala Big Five Inventory (BFI) versi Indonesia, terdiri atas 28 aitem favorable dan 16 aitem unfavorable. Setiap aitem memiliki lima pilihan jawaban yaitu: sangat tidak setuju, sedikit tidak setuju, antara setuju dan tidak setuju, sedikit setuju, dan sangat setuju. BFI versi Indonesia dibuat dari lima dimensi kepribadian Big Five yaitu: extraversion, neuroticism, openness, conscientiousness, dan agreeableness. BFI Versi Indonesia memiliki content validity yang baik dan tingkat reliabilitas yang tinggi untuk masingmasing dimensi: extraversion $=0,73 ; \quad$ agreeableness $=0,76 ; \quad$ conscientiousness $=0,78$; neuroticism $=0,74$; openness $=0,79$ (Ramdhani, 2012).

\section{TEKNIK PENGOLAHAN DATA}

Teknik pengolahan data dalam penelitian ini menggunakan uji korelasi Pearson 
product moment correlation untuk melihat apakah ada hubungan antara dimensi kepribadian Big Five dengan adiksi internet. Sebelum melakukan uji korelasi, peneliti akan melakukan uji asumsi normalitas dan linieritas. Jika uji normalitas dan linieritas tidak terpenuhi, maka dilakukan uji korelasi non- parametrik Kendall's Tau b.

\section{HASIL PENELITIAN DAN DISKUSI}

\section{HASIL PENELITIAN}

Uji normalitas menunjukkan hasil sebagai berikut: (1) Adiksi internet memiliki nilai sig 0,000; (2) Extraversion memiliki nilai sig 0,200; (3) Agreeableness memiliki nilai sig 0,007; (4) Conscientiousness memiliki nilai sig 0,002; (5) Neuroticism memiliki nilai sig 0,003; (6) Openness memiliki nilai sig 0,200. Keenam variabel dikatakan berdistribusi normal bila memiliki nilai $p>0,05$. Dari hasil tersebut, uji normalitas dikatakan tidak normal dikarenakan terdapat empat variabel yang datanya tidak terdistribusi normal (adiksi internet, agreeableness, conscientiousness, dan neuroticism).

Sedangkan untuk uji linieritas menunjukkan hasil sebagai berikut: (1) Adiksi internet - extraversion memiliki nilai sig 0,999; (2) Adiksi internet - agreeableness memiliki nilai sig 0,276; (3) Adiksi internet - conscientiousness memiliki nilai sig 0,060; (4) Adiksi internet - neuroticism memiliki nilai sig 0,032; (5) Adiksi internet - openness memiliki nilai sig 0,400. Hubungan antar variabel dikatakan linier jika $\mathrm{p}<0,05$. Dari hasil tersebut, uji linieritas dikatakan tidak terpenuhi dikarenakan hanya dimensi neuroticism yang linier dengan adiksi internet.

Karena hasil uji normalitas dan linieritas tidak terpenuhi, maka peneliti menggunakan metode analisis non-parametrik Kendall's Tau b. Hasil dari uji hubungan tersebut menunjukkan bahwa hanya neuroticism yang memiliki hubungan dengan adiksi internet $(r=0,121, p=0,034 ; p<0,05)$. Sedangkan hasil hubungan untuk dimensi lainnya adalah sebagai berikut:

a. Adiksi internet-extraversion $(r=0,026, p=0,645)$

b. Adiksi internet-agreeableness $(r=-0,023, p=0,693)$

c. Adiksi internet-conscientiousness $(r=-0,099, p=0,086)$

d. Adiksi internet-openness $(r=-0,015, p=0,796)$

\section{DISKUSI}

Hasil uji hubungan menunjukkan bahwa neuroticism memiliki hubungan positif $(r=0,121$, $p=0,034)$ dengan adiksi internet, namun cenderung lemah. Hasil tersebut sejalan dengan 
penelitian Gogi, Dayala dan Rayala (2018) yang hanya menemukan hubungan antara dimensi neuroticism dengan adiksi internet. Menurut beberapa penelitian (Gogi, Dayala \& Rayala, 2018; Ross, Orr, Sisic, Arseneault, Simmering, \& Orr, 2009), orang dengan neuroticism yang tinggi cenderung bergantung pada internet untuk berinteraksi dengan orang lain karena mereka umumnya sangat protektif dengan informasi pribadi mereka.

Untuk dimensi extraversion, berbagai penelitian menunjukkan hasil yang berbeda, seperti Muller, Beutel, Egloff, dan Wolfling (2013) serta Blachnio dan Przepioka (2016) yang menemukan korelasi negatif dengan adiksi internet. Sedangkan hasil penelitian dari Andreassen dkk (2013) menunjukkan korelasi positif meski tidak terlalu signifikan. Zhou dkk (2016) menyatakan bahwa hal ini terjadi karena orang dengan extraversion tinggi tidak membutuhkan internet untuk bersosialisasi, namun mereka dapat mengalami adiksi karena memiliki trait impulsif dan dorongan untuk mencari stimulus.

Berbeda dengan extraversion, para peneliti umumnya sepakat bahwa agreeableness yang tinggi dapat menjadi faktor protektif dari adiksi internet (Muller dkk, 2013; Blachnio \& Przepiorka, 2016, Zhou dkk, 2016; Andreassen dkk, 2013). Agreeableness yang tinggi membuat seseorang mudah menyesuaikan diri dengan lingkungan sehingga mereka tidak memerlukan dukungan sosial di internet. Namun, individu dengan agreeableness yang dominan cenderung enggan menghadapi permasalahan sehingga rentan menggunakan internet sebagai tempat pelarian (Andreassen dkk, 2013; Ohorella dan Nu'Man, 2009).

Dimensi openness memiliki hasil yang juga bervariasi, yaitu memiliki hubungan negatif dengan adiksi internet (Blachnio \& Przepiorka ,2016; Muller, 2013), tidak ada hubungan (Andreassen dkk, 2013), maupun memiliki hubungan berarah positif sekaligus negatif (Zhou dkk, 2016). Hasil ini terjadi karena dimensi openness memiliki dorongan unutk mencari pengalaman baru. Trait ini dapat menjadi faktor protektif bila dorongan tersebut digunakan untuk mencari pengalaman di dunia nyata. namun dapat menjadi faktor resiko karena dapat membuat individu menghabiskan banyak waktu di internet yang juga menyediakan banyak hal-hal baru (Zhou dkk, 2016).

Terakhir, conscientiousness adalah dimensi yang dianggap sebagai faktor protektif dari adiksi internet, dikarenakan berbagai penelitian di Eropa menunjukkan hubungan negatif antara conscientiousness dengan adiksi internet (Muller dkk, 2013; Blachnio \& Przepiorka, 2016; Andreassen dkk, 2013). Namun, penelitian pada masyarakat Asia menunjukkan hasil yang tidak konsisten, dimana penelitian di India oleh Gogi, Dayala, Rayala (2018) dan Pandya (2015) mendapati tidak adanya hubungan antara adiksi internet dengan conscientiousness. Sedangkan Zhou dkk (2016) menemukan bahwa remaja 
Tiongkok yang memiliki conscientiousness tinggi memiliki tingkat adiksi internet yang rendah. Hal ini kemungkinan dikarenakan perbedaan budaya antara Asia dan Eropa sehingga mempengaruhi variabel penelitian, khususnya Big Five. Mastuti (2005) menambahkan dimensi morality pada kepribadian Big Five untuk konteks Indonesia.

Peneliti menganggap bahwa keterkaitan adiksi internet dengan kepribadian Big Five pada masyarakat Asia, khususnya Indonesia masih perlu dikaji melalui penelitianpenelitian berikutnya, mengingat adiksi internet adalah fenomena yang semakin merebak di Indonesia.

\section{KESIMPULAN DAN SARAN}

\section{KESIMPULAN}

Kesimpulan yang didapat dari penelitian ini yaitu:

a. Terdapat hubungan antara tingkat adiksi internet dengan dimensi kepribadian neuroticism pada mahasiswa di Surabaya.

b. Tidak terdapat hubungan antara tingkat adiksi internet dengan dimensi kepribadian extraversion pada mahasiswa di Surabaya.

c. Tidak terdapat hubungan antara tingkat adiksi internet dengan dimensi kepribadian agreeableness pada mahasiswa di Surabaya.

d. Tidak terdapat hubungan antara tingkat adiksi internet dengan dimensi kepribadian openness pada mahasiswa di Surabaya.

e. Tidak terdapat hubungan antara tingkat adiksi internet dengan dimensi kepribadian conscientiousness pada mahasiswa di Surabaya.

\section{SARAN}

Penelitian selanjutnya diharapkan menggunakan subjek lebih banyak dan lebih mempertimbangkan hasil-hasil penelitian pada masyarakat Asia. 


\section{DAFTAR PUSTAKA}

Andreassen, C.S., Griffiths, M.D., Gjertsen, S.R., Krossbakken, E., Kvam, S., \& Pallesen, S. (2013). The relationships between behavioral addictions and the five-factor model of personality. Journal of Behavioral Addictions, 2(2), 90-99

Arnett, J. J. (2000). Emerging adulthood: A theory of development from the late teens through the twenties. American Psychologist, 55(5), 469-480

Blachnio, A. \& Przepiorka, A. (2016). Personality and positive orientation in internet and Facebook addiction: An empirical report from Poland. Computers in Human Behavior, 59, 230-236

Cheng, C. \& Li, A. Y. (2014). Internet addiction prevalence and quality of (real) life: A meta-analysis of 31 nations across seven world regions. Cyberpsychology, Behavior, and Social Networking, 17(12), 755-760

Gogi, P.V., Dayala, P.P., \& Rayala, S.B.S. (2018). A study on prevalence of internet addiction in medical students and its relationship with personality traits. ParipexIndian Journal of Research, 7(2), 53-54

Goldberg, Lewis R. (1990). An alternative "description of personality": the Big-Five factor structure. Journal of Personality and Social Psychology, 59 (6), 1216-1229

Hall, A. S. \& Parsons, J. (2001). Internet addiction: college student case study using best practices in cognitive behavior therapy. Journal of Mental Health Counseling, 23 (4), 312-327

Kementrian Komunikasi dan Informatika Republik Indonesia. (2013). Kominfo: Pengguna internet di Indonesia 63 juta orang. Diakses dari https://kominfo.go.id/index.php/content/detail/3415/Kominfo+\%3A+Pengguna + Inter $\underline{\text { net }+ \text { di }+ \text { Indonesia }+63+\text { Juta }+ \text { Orang/0/berita satker }}$

Mastuti, E. (2005). Analisis faktor alat ukur kepribadian Big Five (adaptasi dari IPIP) pada mahasiswa suku Jawa. INSAN, 7(3), 264-276. Diunduh dari https://www.researchgate.net/profile/Endah_Mastuti/publication/311737294 Analisis_Faktor_Alat_Ukur_Kepribadian_Big_Five_Adaptasi_dari_IPIP pada Mahasiswa Suku Jawa/links/5858ac6908ae3852d2544790.pdf 
Muller, K.W., Beutel, M. E., Egloff, B., Wolfling, K. (2013). Investigating risk factors for internet gaming disorder: A comparison of patients with addictive gaming, pathological gamblers and healthy controls regarding the Big Five personality traits. European Addiction Research. Advance online publication. doi: 10.1159/000355832

Nugraini, I \& Ramdhani, N. (2016). Keterampilan sosial menjaga kesejahteraan psikologis pengguna internet. Jurnal Psikologi, 43(3), 183-193

Nugraini, I. (2015). Keterampilan sosial sebagai mediator antara hubungan kecanduan internet dan kesejahteraan psikologi pada remaja. Skripsi tidak diterbitkan. Yogyakarta: Universitas Gajah Mada

Ohorella, R. A., \& Nu'Man, T. M. (2009). Big Five personality dengan kecanduan internet. Skripsi tidak diterbitkan. Yogyakarta: Universitas Islam Indonesia

Pandya, Mohit M. (2015). Internet addiction and personality traits among youths of Rajkot District. The International Journal of Indian Psychology, 2(2), 105-109

Ramdhani, N. (2012).Adaptasi bahasa dan budaya inventori Big Five. Jurnal Psikologi, $39(2), 189-207$

Ross, C., Orr, E.S., Sisic, M., Arseneault, J.M., Simmering, M.G., \& Orr, R.R. (2009). Personality and motivations associated with Facebook use. Computers in Human Behavior, 25(2), 578-586. Diunduh dari https://scholar.uwindsor.ca/cgi/ viewcontent.cgi?referer=https://scholar.google.com/\&httpsredir=1\&article=1031\&co ntext $=$ psychologypub

Statista: The Statistic Portal: Statistic and Studies from more than 18.000 sources. (2017). Number of internet users in Indonesia from 2015 to 2022 (in millions) [On-line] diambil pada tanggal 8 November 2017 dari https://www.statista.com/statistics/ 254456/number-of-internet-users-in- indonesia/

Wallace, P. (2014). Internet addiction disorder and youth. Embo Reports. Advance online publication. doi: 10.1002/embr.201338222

Wasito, H., Bala, A., Wismanto, J. B., Kurniawati, L., Nababan, M., Krisnadewara, D., Santosa, R., Suwarsono, \& Rostiawati, Y. (1990). Pengantar metodologi penelitian: Buku panduan mahasiswa. Jakarta: Asosiasi Perguruan Tinggi Katolik

Young, K. S. \& Abreu, C. N. D. (2011). Internet addiction: A handbook and guide to evaluation and treatment. New Jersey: John Wiley \& Sons, Inc

Young, K (n.d.). Surfing not studying: Dealing with internet addiction on campus. [Online]. Diunduh pada tanggal 28 November 2017 dari 
http://netaddiction.com/articles/surfing_not_studying.pdf

Zhou, Y., Li, D., Li, X., Wang, Y., \& Zhao, L. (2016). Big five personality and adolescent internet addiction: The mediating role of coping style. Addictive Behaviors. Advance online publication. doi: 10.1016/j.addbeh.2016.08.009 